Covered in: Web of Sciences (WOS); EBSCO; ERIH+; Google Scholar; Index Copernicus; Ideas RePeC; Econpapers; Socionet; CEEOL; Ulrich ProQuest; Cabell, Journalseek; Scipio; Philpapers; SHERPA/RoMEO repositories; KVK; WorldCat; CrossRef; CrossCheck

2018, Volume 10, Issue 1, pages: 28-36 | doi: https://doi.org/10.18662/rrem/14

\section{Organizing the Swimming Traineeship by Using Coaching Methods}

\section{Valeria BALAN ${ }^{1} *$, Anna Maria ION ${ }^{2}$}

${ }^{1}$ National University of Physical Education and Sport, Bucharest, Romania, valiswim@yahoo.com Corresponding author

2 "Carol Davila" University of

Medicine and Pharmacy, Bucharest, Romania, annamariafinta@yahoo.com

\begin{abstract}
Currently, the educational activity of a teacher is always facing many challenges to which teacher must respond and timely resolve. Training for an educational career starts since the first academic year and continues during all the study years within the license cycle. But the student should not be trained only at theoretical level but also to be put in the situation to apply the theoretical knowledge and skills acquired, during the traineeships. Such traineeships shall develop under the coordination of a group of experts who help the student and render him/her in the role of instructional - educational process coordinator. To this end, the group of experts benefits of a set of coaching methods that facilitates the activity during the traineeship. Those methods could not be arbitrary used but in connection to the traineeship contents and goals. All such initiative has the role to prepare the student for the educational career he/she opted for.
\end{abstract}

Keywords: Swimming, traineeship, coaching methods.

How to cite: Balan, V., \& lon, A.M. (2018). Organizing the Swimming Traineeship by Using Coaching Methods. Revista Romaneasca pentru Educatie Multidimensionala, 10(1), 28-36. https://doi.org/10.18662/rrem/14 


\section{Introduction}

Currently, the educational activity of a teacher is always facing many challenges to which teacher must respond and timely resolve. At the same time, the teacher must permanently accommodate both with the knowledge and skill levels acquired by different groups of pupils he/she contacts and with the knowledge and skill levels of the other individuals, members of the school community where he/she conducts his/her activity. This is the reason for which the teacher must be very well educated and trained since the time when he/she opted to follow an educational career.

Since the first academic year, the future teacher shall learn the different curriculum plan study objects and acquire not only the „knowledge and skills required to teach" (specialist knowledge) (Paun, 2013) but also the "knowledge and skills required to teach and organize the pupil teaching processes", which come from the specialist teaching and psycho-pedagogy fields of theoretical and practical nature. All those skills shall help the future teacher to resolve some special issues appeared in a certain field of activity (Stanescu, 2012).

For this reason, the specialist practicum is a key component of the process of preparing the future teacher, under which this one applies the theory learned but also discovers other theoretical knowledge able to supplement his/her training.

\section{Theoretical Background}

During the specialist traineeship, the student must be guided and advised by a group of experts that facilitates the knowledge and renders easier the transition from theory to practice, from being in the desk to being in front of the collective of athletes. The group of experts, contributing to the ,initial training and professional inclusion process"(Paun, 2013), shall consist of the:

- Tutor - ,individual holding a deep theoretical education, who acquired a vast practical expertise. His/her duty is to supervise and support the future specialists" (Ezechil, 2013). This shall implement the training program intended to the future teachers, support them in the process of „accommodation with the practical part of the exercise of teaching functions", assess the outcomes obtained in educating the future teachers, aso (Paun, 2013).

During the swimming traineeship based on the coaching-type strategy, the tutor shall exercise several roles, namely: 

traineeship;

To establish the teaching strategies to be used during the

$\square$ To provide teaching project models specific for the sportive swimming discipline;

$\square$ To conduct demonstrative activities for students, giving them the opportunity to observe and note the manner in which the swimming coaching class develops;

$\square$ To provide solutions for the issues raised by students;

$\square$ To ensure the feedback after every class, to correct the errors observed during the relevant activity and to provide solutions applicable in the future.

- Mentor - teacher with experience and enjoying of recognition in the field (Ezechil, 2013) that monitors, coordinates and supports the student during the traineeship developed within the sportive club. The mentorship activity is very important because, it is performed in the professional industry within the future graduates will integrate" (Paun, 2013). Moreover, the activity performed by the mentor throughout the traineeship is very important because the latter must know to motivate the students „for a certain cause" (Vaina, Pop, Strete, \& Gurau, 2007), not only "to produce teachers". The mentor must help students and make them understanding that they must permanently develop professionally and getting confidence in their own capacities.

From point of view of coaching-type strategies, the mentor exercises the following roles:

$\square$ To plan what to do with the student during the traineeship;

$\square$ To explain how and where the relevant tasks shall be fulfilled;

$\square$ To show how the relevant tasks must be achieved;

$\square$ To create opportunities and organize the process of acquiring the skills/abilities he/she wants to develop to the students;

$\square$ To provide feedback to students whenever required, to correct students' errors and to encourage the students;

$\square$ To reward the activities well performed;

$\square$ To assess the activity performed by the student throughout the traineeship period;

$\square$ To explain the manner of conducting the assessment.

\section{Argument of the paper}

The group of experts shall synergic act within the complex coaching strategy and shall always take into consideration the understanding-focused 
teaching. By coaching, the future teachers shall know the manner of functioning of a sportive club and implement in practice, the teaching learning - assessment process.

Ezechil (Ezechil, 2013) specifies that the role of coach may be fulfilled both by the mentor and the tutor. Important is to have a mentor or tutor very well educated, with a wide professional experience, close to the trainees whose activity the mentor/tutor must observe. Also, the mentor/tutor must highlight the positive aspects in the activity of those coordinated by him/her, to criticize them when is necessary and to provide them with solutions for the different issues occurring in the practical activity.

In the practical activity, among the practicum coordinator (the tutor), the swimming teacher (the mentor) and the student must be always a collaboration relationship. Together, they establish the activity timetable, the class(es) when the trials and final lesson shall be conducted, as well as the other activities implying the student, as participation along with athletes in the swimming competitions, participation in the organization of a swimming competition, participation in a swimming competition in capacity of referee, aso.

\section{Arguments to support the thesis}

Organization of the classes within the traineeship in the swimming discipline gets a different meaning, specific for the sportive disciplines. By such classes, future coaches are provided with the training of their skills crucial for the exercise of the swimming coach profession (Palasan \& Voinea, 2012).

The specialist swimming traineeship management consist of „elaboration of a coherent overview over the whole traineeship and establish of functional correlations between goals - methods - means - assessment forms" (Ezechil, 2013)- The specialists' opinion is that the coaching methods used within the traineeship must be approached in terms of the aspect of ,functional and operational relationships existing among the above mentioned components" (Ezechil, 2013).

\section{Arguments to argue the thesis}

\subsection{Aim of the paper}

Under such circumstances, this work aims to describe the coaching methods used in the swimming traineeship. 
For those methods, we specify also the contents and goals of the swimming traineeship in order to highlight the usability of the coaching-type methods used:

Traineeship contents: observation and registration of the training conducted with the athletes of different ages, for two swimming sportive disciplines, namely water polo and swimming, as well as of the manner of development of the swimming competitions organized for athletes of different ages in water polo and swimming in the training notebook; participation as assistant referee in water polo and swimming competitions; participation as assistant referee in swimming competitions; assistance in the activity developed within the national and local activity organization bodies.

Traineeship goals: the students' ability increase by adding the notions necessary to understand the evidence and planning documents; elaboration of the planning documents; training the observation ability - recording of the coaching classes; training the ability to communicate with the athletes, coaches, other members of the multidiscipline team; training the ability to organize sportive swimming competitions; training the capacity to conduct the class sequences and/or the coaching lessons; training the ability to collaborate with the national and local organizational bodies.

\subsection{Methods used in the teaching practice-,,coaching” vision}

According to the specialists, there are several methods, techniques and procedures used to organize the traineeship under „coaching” vision. From our point of view, for the swimming traineeship, the following coaching methods can be used:

- Lesson systematic observation - is considered by Ezechil (Ezechil, 2013)as „one of the first form of practicum”. It consists of active, intentional, systematic and intensive perception of coaching lessons (either the demonstrative lesson conducted by the mentor, or the trial/final lessons conducted by the colleagues, members of the traineeship group), with the aim of collecting accurate and objective data.

During the swimming traineeship developed in the initiation centers, students come more in contact with the novice athletes (children of 7 to 10 years old), compared to performance and high-performance groups, to which the access is limited. Within the coaching classes with the novice athletes, students may:

Recognize the components of an instructional - educational process and the specifics of each of the components; 
mentor;

Accommodate with the planning documents elaborated by the

Identify the manner of approaching different situations that might occur during the activity period;

$\square$ Fill-in consciously and responsible the traineeship notebook;

$\square$ Discuss and critically consider the aspects observed during the classes and clarify the ambiguous aspects.

Observation of the activity developed by the mentor or the traineeship team colleagues shall not be conducted arbitrary but it shall be recorded in the traineeship notebook, based on the ,graphic and cognitive organizers" materialized under the form of Observation Sheet in case of swimming traineeship (Table 1):

Table 1. Observation Sheet Structure

\begin{tabular}{lll}
\hline Lesson's part & Means used & $\begin{array}{l}\text { Remarks/queries/positive aspects } \\
\text { found/questions }\end{array}$ \\
\hline Introductive & \\
Fundamental & \\
Conclusion & \\
\hline
\end{tabular}

The systematic observation can be supplemented also by resolving, by the students, of some additional tasks at the end of the lessons observed. Those tasks are indicated at the beginning of the lesson and they have the role to focus the attention and cognitive energy of the observer (Ezechil, et. al, 2013). For the swimming lesson, those tasks may aim both aspects related to the attitude of the mentor during the classes, and learning aspects related to athletes (i.e., errors very frequent in the technical execution of the swimming procedures).

- Presentation and analysis of the curriculum documents - according to the specialists' opinion, this coaching method applies in two stages. During the first stage, the tutor presents to the students, the curriculum documents they will work with during the traineeship period, namely the curriculum, the calendar planning, the methodological guides etc. During the second stage, the mentor presents to the students in practicum, the teacher portfolio where there are all the special curriculum documents.

- Teaching in real time - it is an important method in training the skills necessary to the future teacher. The peculiarity of this method is the support granted to the student by the mentor or tutor. Such support may occur before beginning the lesson (guiding the student to conceive the 
teaching project), during the lesson (mentor introduces the student to the collective of athletes „to be coached" by the student) and at the end of the lesson (lesson analysis conducted by the student).

- Teaching in team - it is a coaching method often used during the swimming traineeship, especially during its first stage. In such case, teams of two students will be organized, each of them following to conduct a stage of the lesson. They must establish which stage will conduct each of them, to design together the lesson, to establish the goals to be reached and the content of each stage.

Exercising professional roles through experiential learning - it means, according to the opinion of Ezechil (Ezechil, Şerbănescu, Neacşu, Langa, Soare, Trif, Glava, \& Stan, 2013), the implementation of the „learning by doing" notion. By such method, students are trained in the „direct experiencing of professional behaviours” (Ezechil, 2013) that enable them to acquire new knowledge and abilities.

This method can be implemented through the involvement of students in organizing swimming competitions and implies the participation of the whole group of students in the coaching activity. To illustrate, we will show the steps that must be followed to organize a Swimming Championship.

Before organizing a competition, students must assist, along with the tutor, at a swimming competition. By this, students are engaged in observing the concrete method of organizing a competition and are helped to understand what they will have to do for the competition they will organize.

The steps to be undertaken by the students are:

$\square$ Establishing the competition programme (the swimming trials of the National Swimming Championship shall be taken into consideration) contests shall be organized both for female students and male students, under the form of individual trials and team trials (medley relays);

$\square$ Specifying the criteria for identifying the winners;

$\square$ Identifying the number of prizes to be granted;

$\square$ Submitting the competition programme to the Swimming Commission for approval;

$\square$ Identifying the venue for conducting the competition (the swimming pool);

$\square$ Identifying the potential sponsors;

$\square$ Drawing up and submission of swimming pool leasing/booking application for the competition duration;

$\square$ Drawing up and submission of requests to sponsors; 
Establishing the roles for every student during the competition duration: series organizer - referee, starter referee, back-kick referee, timing referee, secretary - referees, aso;

$\square$ Announcing the competition to all sport clubs;

$\square$ Ensuring the development of the competition (with the identification of the winners);

$\square$ Rewarding of the winners;

Sending of the official results to all participating sport clubs.

\section{Conclusions}

Training the future teachers implies both a theoretical education and a practical training. The theoretical education aims to acquire of general knowledge, specialist knowledge and teaching knowledge that will be frequently used in the activity with the sports athletes. The practical training shall be ensured through the traineeships special for each discipline and shall put the student in the position of leader of the instructional - educational process.

Use of coaching methods in the swimming traineeship facilitates acquire of new skills by the student, putting him/her, at the sale time, in the position to implement the skills and abilities acquired during the theoretical classes.

The tutor - mentor - student(s) collaboration is crucial and trains the future teacher concerning the teaching - learning - assessment process.

\section{Acknowledgements}

Both authors had an equal contribution to this study and are main authors.

\section{References}

Ezechil, L. (2013). Managementul practicii pedagogice. In E. Paun \& L. Ezechi (Eds.), Suport de curs - modulul 3 (pp. 19 -71). Bucharest: Matrix Rom.

Palasan, T., \& Voinea, M. (2012). Ghid pentru practica pedagogica. Universitatea Transilvania din Brasov. Facultatea de Psihologie si Stiintele Educatiei

Paun, E. (2013). Preambul. Practica pedagogica in actualul context al profesionalizarii pentru cariera didactica. Metode şi tehnici de coaching folosite pe perioada practicii pedagogice, Suport de curs - modulul 3. 
Stanescu, M. (2012). Didactica educatiei fizice. Bucuresti: Ed. Universitara. Vaina, R., Pop, V., Strete, M., \& Gurau, D. (2007). Calitatile unui bun mentor. In V. Marcu \& M. Marinescu (Eds.), Educația omului de ari, pentru lumea de maine. (4 ed.). Oradea: Universitatea din Oradea. 